\title{
Experimental and Analytical Studies on Soft Clay Beds Reinforced with Bamboo Cells and Geocells
}

\author{
A. Hegde ${ }^{1}$ T. G. Sitharam ${ }^{1}$
}

Received: 4 March 2015/Accepted: 24 March 2015/Published online: 1 April 2015

(c) Springer International Publishing AG 2015

\begin{abstract}
This manuscript deals with the experimental and analytical studies carried out to explore the possibility of using naturally available bamboo to increase the bearing capacity of the soft soil. In order to extract the additional confinement effect on the soil, 3 dimensional-cells are formed from the locally available bamboo known as bamboo cells. The performances of the bamboo cells are compared with the commercial geocells. Further, a planar reinforcement in the form of bamboo grid was provided at the base of bamboo cells and the performance was compared with the clay bed reinforced with the combination of geocell and geogrid. The results of the laboratory plate load tests suggested that the ultimate bearing capacity of the clay bed reinforced with combination of bamboo cell and bamboo grid was about 1.3 times higher than the geocell and geogrid reinforced clay beds. In addition, a substantial reduction in the settlement was also observed. An analytical model was also proposed to estimate the bearing capacity of the clay bed reinforced with bamboo cells and bamboo grids. The model comprised of three mechanisms, namely the lateral resistance effect, vertical stress dispersion effect and membrane effect. The results predicted from the analytical model were found to be in good agreement with the experimental results. In a larger perspective, this study proposes a cost effective ground improvement technique in soft soils as an alternative to geocells and geogrids.
\end{abstract}

A. Hegde

amarnathhegde@gmail.com

T. G. Sitharam

sitharam@civil.iisc.ernet.in

1 Department of Civil Engineering, Indian Institute of Science, Bangalore 560012, India
Keywords Bamboo - Geocells - Geogrids · Bearing capacity $\cdot$ Soft clay $\cdot$ Plate load test

\section{List of symbols}

$B \quad$ Width of the footing (m)

$B_{\mathrm{g}} \quad$ Width of basal bamboo grid (m)

$C_{\mathrm{c}} \quad$ Coefficient of curvature (dimensionless)

$C_{\mathrm{u}} \quad$ Coefficient of uniformity (dimensionless)

$d \quad$ Surface deformation (m)

$D_{\mathrm{r}} \quad$ Height of the bamboo cell (m)

$D_{10} \quad$ Effective particle size $(\mathrm{mm})$

$e_{\max }$ Maximum void ratio (dimensionless)

$e_{\text {min }}$ Minimum void ratio (dimensionless)

$\mathrm{I}_{\mathrm{f}} \quad$ Bearing capacity improvement factor (dimensionless)

$K_{\mathrm{s}} \quad$ Modulus of subgrade reaction $\left(\mathrm{kN} / \mathrm{m}^{3}\right)$

$\Delta P$ Total increase in load carrying capacity foundation soil due to the presence of the reinforcement $(\mathrm{kPa})$

$\Delta P_{1} \quad$ Increase in the load carrying capacity due to the lateral resistance effect $(\mathrm{kPa})$

$\Delta P_{2} \quad$ Increase in the load carrying capacity due to the vertical stress dispersion effect $(\mathrm{kPa})$

$\Delta P_{3} \quad$ Increase in the load carrying capacity due to the membrane effect $(\mathrm{kPa})$

$P_{\mathrm{r}} \quad$ Pressure applied on the bamboo cell reinforced soil $(\mathrm{kPa})$

$P_{\mathrm{u}} \quad$ Pressure applied on the unreinforced soil $(\mathrm{kPa})$

$S \quad$ Footing settlement measured at the surface (m)

$T \quad$ Tensile strength of bamboo $(\mathrm{kN} / \mathrm{m})$

$\alpha \quad$ Horizontal angle of the tensional force $\mathrm{T}$ (degrees)

$\beta \quad$ Load dispersion angle (degrees)

$\delta \quad$ Angle of shearing resistance between the bamboo cell wall and soil (degrees)

$\varphi \quad$ Angle of internal friction of infill soil (degrees) 
Shear strength between the bamboo cell wall and the infill soil $(\mathrm{kPa})$

\section{Introduction}

Nowadays, emerging countries like India are giving enormous importance to infrastructural growth to keep up the pace with the economic growth and cater the needs of a burgeoning population. In the process, large networks of railroads, ports and airports are being constructed across the country. Most often, these structures are constructed on the challenging ground conditions. In such situations, geosynthetic reinforcements involving geocells and geogrids are most favoured techniques to improve the bearing capacity of the soil. Geosynthetic materials can offer innovative and sustainable solutions to complex geotechnical problems. This study intends to explore the possibility of using the bamboo as the reinforcement in soft soil as an alternative to the geosynthetic material. The bamboo is cost effective, environmentally friendly material; which possesses higher tensile strength as compared to geosynthetics.

In the present study, bamboo cells and bamboo grids were formed from the locally available bamboo in order to utilize the bamboo effectively. Bamboo cells and bamboo grids resemble their commercial counterpart, namely geocells and geogrids. The idea behind forming bamboo cells is to extract the additional confining effect on the encapsulated soil by virtue of its 3-dimensional shape. Many researchers in the past have demonstrated the beneficial aspects of geocells and its ability to extract additional confinement on the infill soil [1-9]. Hegde and Sitharam [10] observed that the performance of the geocell can be improved by providing the basal geogrid. Hence, in the present study, bamboo grids are also formed similar to geogrids and used below the bamboo cells. Figure 1 shows the photographs of the geocells and the bamboo cells used in the study.

Coincidently, the regions which are facing the soft soil problems also have abundant sources of bamboo e.g. South East Asia, India etc. With the existence of huge sources of bamboo, it can be potentially utilized in various construction practises. But nowadays, the use of the bamboo is restricted to very limited applications such as scaffoldings, roofs, foot bridges etc. The biodegradability of the bamboo is the major concern in the soft soil applications. Bamboo imparts the adequate strength to the soil before it slowly breaks down and mixed with the soil. By the time bamboo breaks down, soft soil also gains the strength due to the process of consolidation and the reinforcement effect may not be required after long time. However, nowadays techniques are also available to increase the durability of the bamboo through impregnation of the preservatives by various means [11].

In the recent past, bamboo poles were directly used to reinforce the soil [12]. There were also instances, where bamboo was used with other materials such as geotextiles, bitumen etc. [13-15]. However, in the present study, contrary to the previous studies, bamboo cells and bamboo grids are used to reinforce the soil. The first half of the manuscript deals with the laboratory model tests performed on the reinforced soft clay beds. The second half of the manuscript describes the analytical formulation to estimate the bearing capacity of the bamboo cell reinforced clay bed. Finally, the results predicted from analytical studies are compared with the experimental results.

\section{Laboratory Model Tests}

\section{Experimental Setup}

Laboratory model plate load tests were conducted on test bed cum loading frame assembly. Foundation bed was
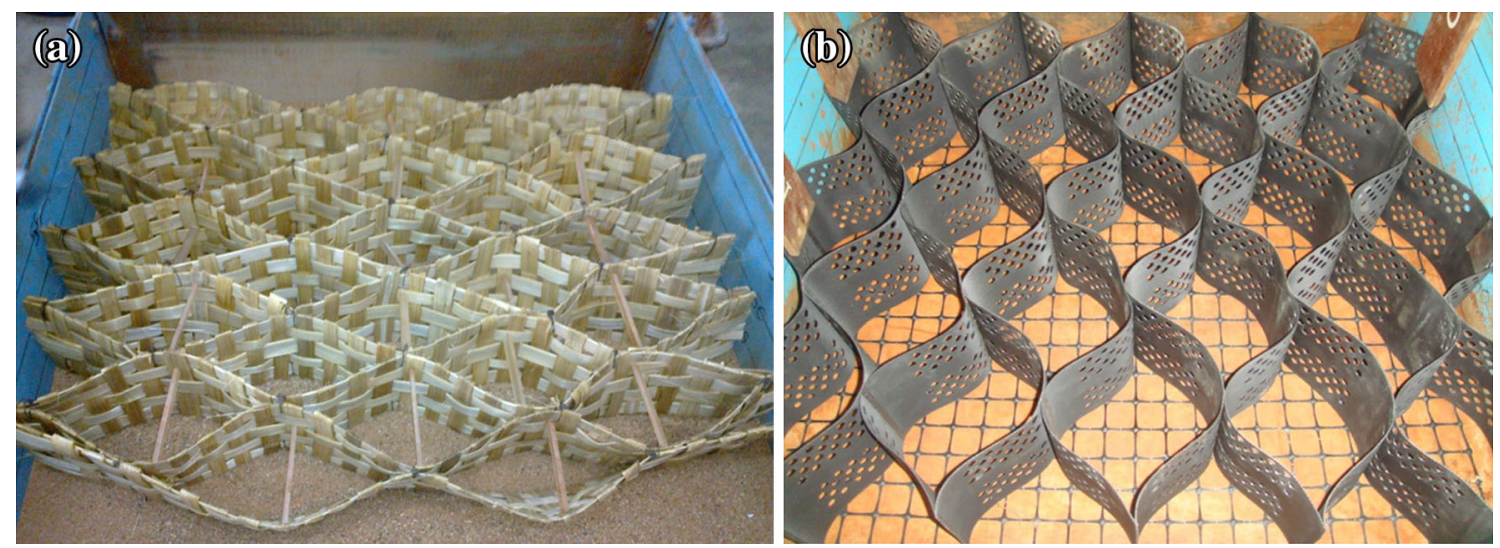

Fig. 1 Photographs: a bamboo cell; $\mathbf{b}$ geocell 


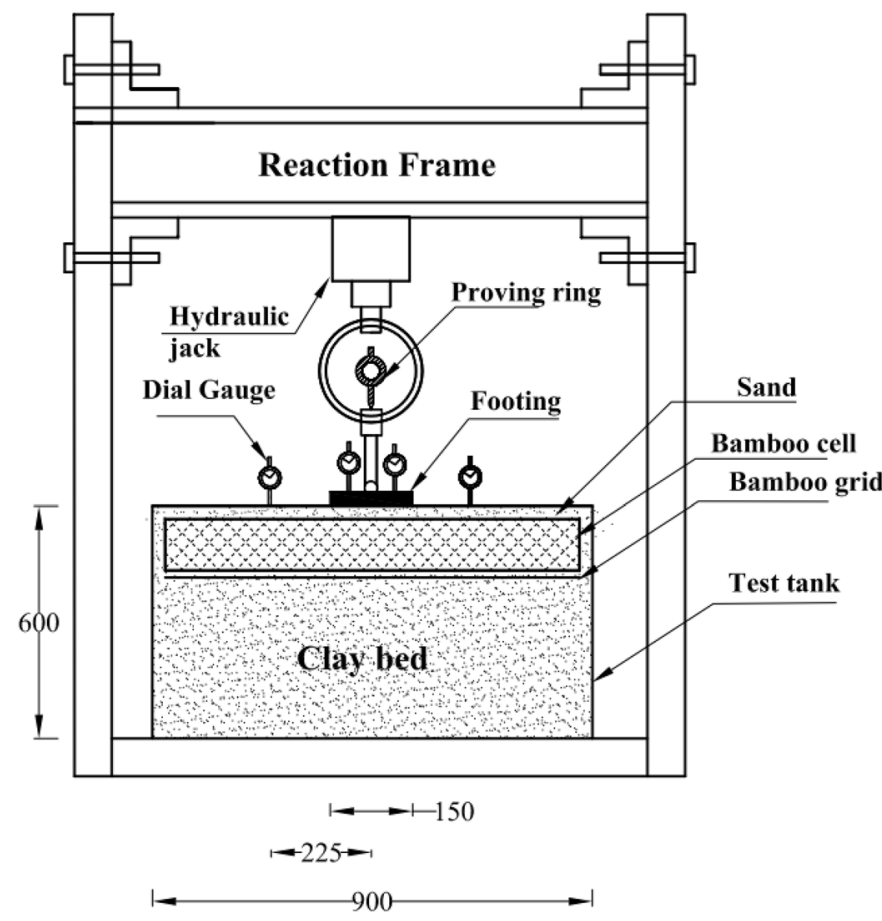

(a)

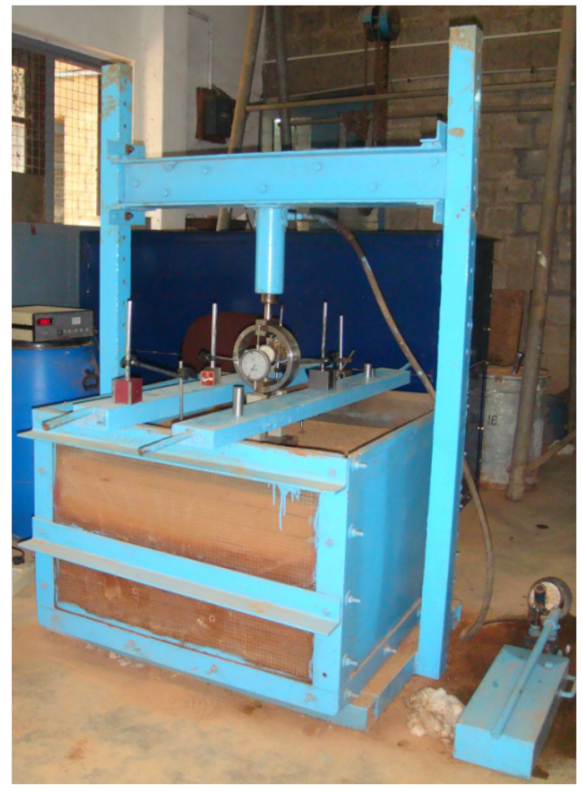

(b)

Fig. 2 Test setup a schematic view; b photographic view

prepared in a test tank with dimension of $900 \mathrm{~mm}$ length, $900 \mathrm{~mm}$ width and $600 \mathrm{~mm}$ height. The footing used in the study was square in shape with $150 \mathrm{~mm}$ sides, $20 \mathrm{~mm}$ thickness made up of rigid steel plate. The details about the design of the experiments are explained elsewhere by Hegde and Sitharam [16]. The distance between the center line of the footing and the edge of the tank used in the present study was about three times the width of the footing (i.e. total width of the tank is six times the width of footing). The height of the tank was four times the width of the footing. According to Selig and Mckee [17] and Chummar [18], the failure wedge below the strip footing on the sand bed will be extended up to a distance of $2-2.5 B$ on either side of the footing. Similarly, the failure wedge will be extended up to the depth of $1.1 B$ ( $B$ is the width of footing) below the footing. Hence, from these observations, it is evident that the tank used in the current investigation is sufficiently large to prevent the influence of the tank boundaries on the results. The base of the footing was made rough by coating a thin layer of sand to it using epoxy glue. Footing was loaded with hand operated hydraulic jack supported against self-reacting frame. The load applied to the footing was measured through a pre-calibrated proving ring, which was placed between hydraulic jack and the footing with the ball bearing arrangement. Figure 2 represents the schematic and photographic view the test setup.

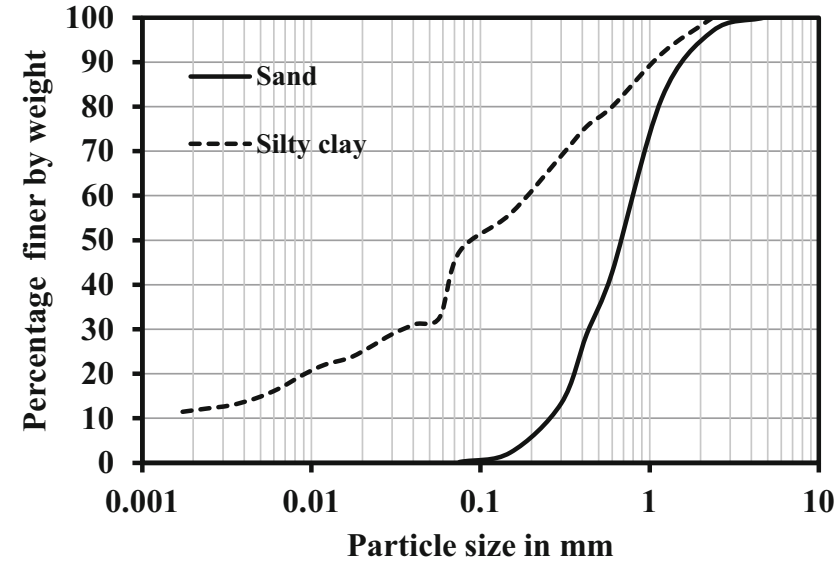

Fig. 3 Grain-size distribution of the materials used in the study

\section{Materials Used}

Foundation bed was prepared using the natural clayey soil of low compressibility (CL). The sand infill used in the experiment was classified as the poorly graded sand (with symbol $S P$ as per Unified Soil Classification System). Grain-size distributions of the sand and clay are shown in Fig. 3. Commercially available high strength Neoloy geocells and biaxial geogrids made from Polypropylene were used in the study. The properties of all the materials used in the study are summarized in Table 1 . The bamboo used in 
Table 1 Summary of properties of different materials used in the study

\begin{tabular}{|c|c|c|c|}
\hline \multicolumn{2}{|l|}{ Reinforcement } & \multicolumn{2}{|l|}{ Soil } \\
\hline Parameters & Quantity & Parameters & Quantity \\
\hline Geocell & & Clay & \\
\hline Polymeric alloy & Neoloy & Specific gravity & 2.66 \\
\hline Cell size $(\mathrm{mm})$ & $250 \times 210$ & Liquid limit (\%) & 40 \\
\hline No. of cells $/ \mathrm{m}^{2}$ & 40 & Plastic limit (\%) & 19 \\
\hline Cell depth $(\mathrm{mm})$ & 150 & Maximum dry density $\left(\mathrm{kN} / \mathrm{m}^{3}\right)$ & 18.2 \\
\hline Strip thickness $(\mathrm{mm})$ & 1.53 & Optimum moisture content (\%) & 13.2 \\
\hline Ultimate tensile strength $(\mathrm{kN} / \mathrm{m})$ & 20 & Clay mineral & Kaolinite \\
\hline Seam peal strength $(\mathrm{N})$ & $2150( \pm 5 \%)$ & Sand & \\
\hline Density $\left(\mathrm{g} / \mathrm{cm}^{3}\right)$ & $0.95( \pm 1.5 \%)$ & Effective diameter, $D_{10}(\mathrm{~mm})$ & 0.26 \\
\hline Short term yield strength $(\mathrm{kN} / \mathrm{m})$ & 20 & Coefficient of uniformity, $C_{\mathrm{u}}$ & 3.08 \\
\hline Geogrid & & Coefficient of curvature, $C_{\mathrm{c}}$ & 1.05 \\
\hline Polymer & Polypropylene & Maximum void ratio, $e_{\max }$ & 0.81 \\
\hline Aperture size (mm) & $35 \times 35$ & Minimum void ratio, $e_{\min }$ & 0.51 \\
\hline Ultimate tensile strength $(\mathrm{kN} / \mathrm{m})$ & 20 & Friction angle, $\varphi\left(^{\circ}\right)$ & 36 \\
\hline Mass per unit area $\left(\mathrm{g} / \mathrm{m}^{2}\right)$ & 220 & & \\
\hline Shape of aperture opening & Square & & \\
\hline \multicolumn{4}{|l|}{ Bamboo } \\
\hline Species & Bamboosa bambos & & \\
\hline Water content $(\%)$ & 23 & & \\
\hline Density (g/cc) & 0.97 & & \\
\hline Ultimate tensile strength $(\mathrm{kN} / \mathrm{m})$ & 253 & & \\
\hline Secant modulus at $2 \%$ strain $(\mathrm{MPa})$ & 5500 & & \\
\hline
\end{tabular}

the study belongs to the Belgaum region in Karnataka state in India. The relatively fresh green bamboo was cut into pieces to obtain a strip of $20 \mathrm{~mm}$ width to a required length. Then the strips are woven together to form a grid. These grids were tied together using galvanized wire to form a shape which resembles the geocells. The joint distances in the bamboo cells were maintained so as to give the pocket sizes equivalent to that of commercial geocells used in the study.

Figure 4a represents the tensile stress-strain behavior of the geocell, geogrid and bamboo. In case of geocell and bamboo, the test sample of width $25 \mathrm{~mm}$ was used for tensile testing. The strain rate applied was $0.1 \%$ of the gauge length of the sample per Sec. Multi-rib tensile strength test was carried out as per ASTM D 6637 [19] to determine the tensile properties of the geogrid. Figure $4 \mathrm{~b}$ shows the photograph of the bamboo sample during the testing. From the Fig. 4a, it is evident that the larger strain (more than $10 \%$ strain) is required in case of geocells and geogrids to mobilize the full tensile strength. However, bamboo can mobilize the full tensile strength at relatively lower strain (less than $3 \%$ ). Because of this reason, in the geotechnical problems involving the small strains/deformations such as foundation problems, bamboo cells are more effective than the geocells and geogrids. In other words, it is advised to limit the bamboo applications in geotechnical problems involving small strains. In addition, the tensile strength of the bamboo was found to be nine times higher than the geocells and geogrids.

\section{Clay Bed Preparation}

The clayey soil was first pulverized and then mixed with a predetermined amount of water. The moist soil was placed in the airtight container for 3-4 days for allowing uniform distribution of moisture within the sample before kneading again. Soil was uniformly compacted in $25 \mathrm{~mm}$ thick layers to achieve the desired height of the foundation bed. Each layer was compacted with 25 numbers of blows using a metal rod by maintaining the constant fall of height. The sides of the tank were coated with Polyethylene sheets to avoid the side friction. By carefully controlling the compaction effort and the water content of the test bed, a uniform test condition was achieved in all the tests. In order to determine the degree of saturation, unit weight, moisture content and undrained shear strength of the soil mass, the undisturbed samples were collected at different location of the test bed. The undrained shear strength of the 
Fig. 4 Tensile test: a stressstrain behavior of different material; b bamboo sample during testing

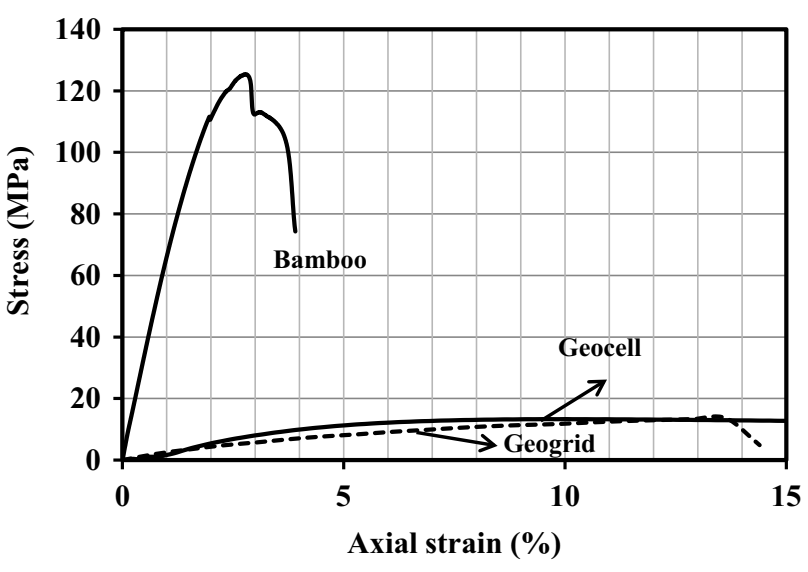

(a)

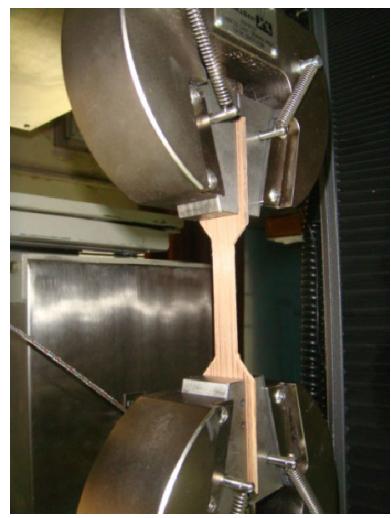

(b) soil was measured using the fall cone apparatus [20]. Table 2 represents the properties of the test bed maintained throughout the testing program.

\section{Testing Procedure}

Above the clay bed, the reinforcements were placed to the full width of the tank. The cell pockets were filled up with the clean sand using pluviation technique to maintain the uniform density. A layer of geotextile was used as a separator between soft clay bed and the sand overlaying it. Upon filling the geocell with the sand, the fill surface was leveled and footing was placed in a predetermined alignment. A manually operated hydraulic jack was used to apply the load. A ball nearing arrangement was used to apply the load at the center of the footing without any eccentricity. The load transferred to the footing was measured through the pre-calibrated proving ring. Loads were applied in steps with equal load increments in each step. The magnitude of each load increment was equal to $0.85 \mathrm{kN}$ and it was equivalent to $38 \mathrm{kPa}$ in terms of footing pressure. Tests were stopped when the settlement of the footing was equal to $40 \%$ of the footing width. Footing settlements were measured through two dial gauges placed on either side of the centre line of the footing. The deformations of the soil surface were measured by dial gauges placed at a distance $1.5 B$ ( $B$ is the width of the footing) from the centre line of the footing on either side. The

Table 2 Properties of the soft clay bed

\begin{tabular}{ll}
\hline Parameters & Values \\
\hline Moisture content & $26 \%$ \\
Degree of saturation & $91 \%$ \\
Unit weight & $18.63 \mathrm{kN} / \mathrm{m}^{3}$ \\
Average dry unit weight & $14.81 \mathrm{kN} / \mathrm{m}^{3}$ \\
Undrained shear strength & $5 \mathrm{kPa}$ \\
\hline
\end{tabular}

footing settlement $(S)$ and the surface deformation $(\delta)$ were normalized by footing width $(B)$ to express them in nondimensional form as $S / B(\%)$ and $d / B(\%)$.

\section{Results and Discussion}

Figure 5 represents the bearing pressure-settlement behaviour of the clay bed reinforced with different types of reinforcements. A substantial increment in the bearing capacity was observed due to the provision of reinforcements as compared to unreinforced clay bed. In case of unreinforced bed, load settlement curve become almost vertical beyond $S / B=5 \%$ indicating the failure of the bed. However, no clear cut failure (i.e. sudden change in the slope of the curve) was observed in the presence of reinforcements. Bamboo cells provided much higher bearing capacity than the geocells. From the load settlement curve, it is obvious that the use of the combination of

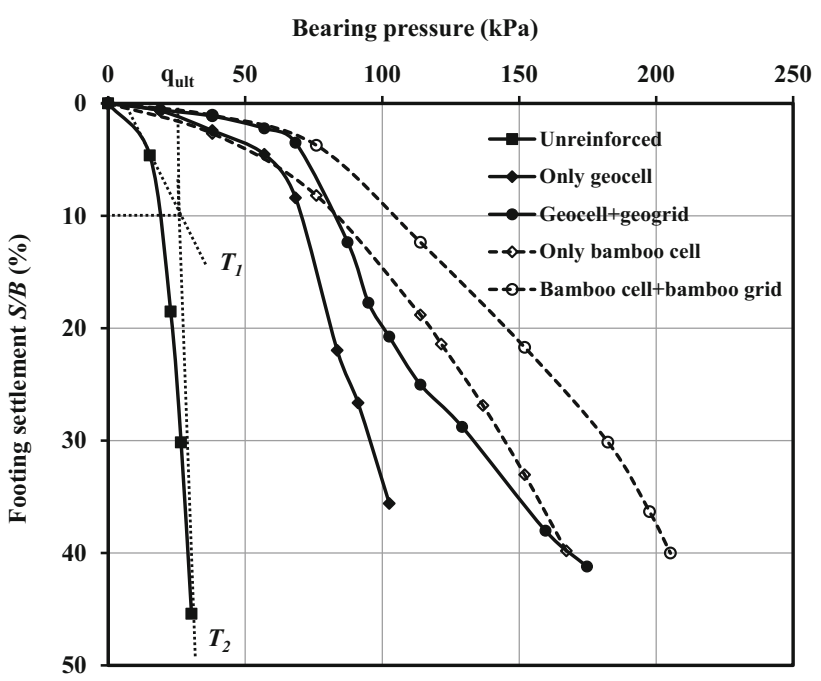

Fig. 5 Bearing pressure-settlement behavior 
geocell and geogrid or combination of bamboo cell and bamboo grid yields a better performance than using geocell or bamboo cell alone. Out of all tested combinations, the performance of the combination of bamboo cells and bamboo grids is found to be better than any other type or combination of reinforcements. The bearing capacity of the clay bed reinforced with bamboo cell and grid found to be 1.2-1.5 times higher than the clay bed reinforced with geocells and geogrids.

The increase in the bearing capacity due to the provision of the reinforcement can be measured through a non-dimensional parameter called bearing capacity improvement factor $\left(I_{\mathrm{f}}\right)$, which is defined as,

$I_{\mathrm{f}}=\frac{q_{\mathrm{r}}}{q_{\mathrm{o}}}$

where, $q_{\mathrm{r}}$ is the bearing pressure of the reinforced soil at the given settlement and $q_{\mathrm{o}}$ is the bearing pressure of unreinforced soil at the same settlement. The improvement factor is same as the bearing capacity ratio, reported by Binquet and Lee [21]. When the $q_{\mathrm{o}}$ is beyond the ultimate bearing capacity of the unreinforced soil, the ultimate bearing capacity $\left(q_{\mathrm{ult}}\right)$ is used instead of $q_{\mathrm{o}}$. Variations of bearing capacity improvement factors with the footing settlement for different tests are shown Fig. 6. $I_{\mathrm{f}}$ value found to increase with the increase in footing settlement. The maximum value of $I_{\mathrm{f}}$ i.e. $I_{\mathrm{f}}=7.2$ was observed in the case of combination of bamboo cell and the bamboo grid. $I_{\mathrm{f}}=7.2$ means the 7.2 times increment in the load carrying capacity of the foundation bed as compared to the unreinforced bed. From the figure, it is evident that the even bamboo cell alone can yield the same performance as that of the combination of geocell and geogrid.

The performance improvement of the foundation bed due to geocell reinforcement can also be quantified in terms

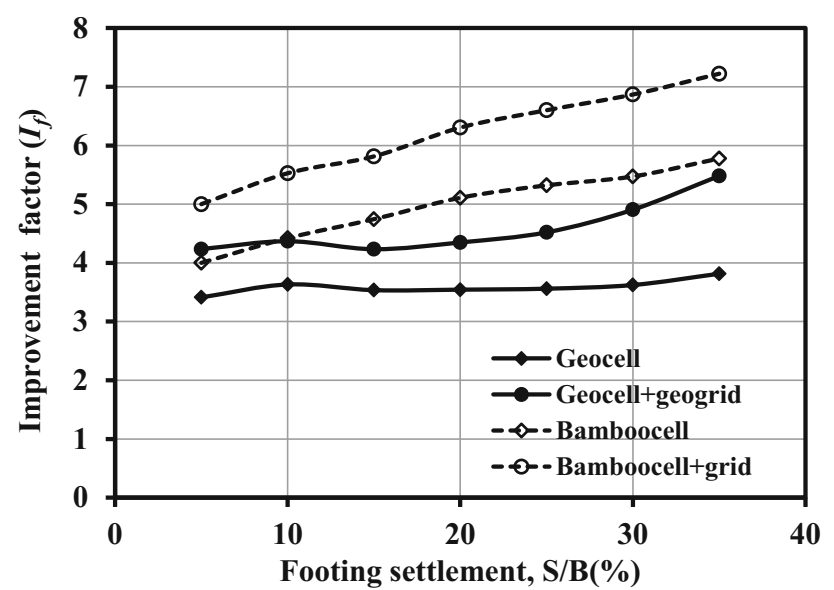

Fig. 6 Variation of bearing capacity improvement factors with footing settlement of the reduction in the settlement of the footing using the parameter called percentage reduction in settlement (PRS). PRS is defined as,

$\operatorname{PRS}=\left(\frac{S_{\mathrm{o}}-S_{\mathrm{r}}}{S_{\mathrm{o}}}\right) \times 100$

where $S_{\mathrm{o}}$ is settlement of the unreinforced foundation bed corresponding to its ultimate bearing capacity. The double tangent method suggested by Vesic [22] was used to estimate the ultimate load bearing capacity $\left(q_{\mathrm{ult}}\right)$ of the unreinforced clay bed as shown in Fig. 5. As per this method, the ultimate bearing capacity is defined as the pressure corresponding to the intersection of the two tangents; one at the early part of the pressure settlement curve $\left(T_{1}\right)$ and the other at the latter part $\left(T_{2}\right)$. In the present case, the ultimate bearing capacity was obtained at a settlement equal to $10 \%$ of the footing width $(S / B=10 \%) . S_{\mathrm{r}}$ is settlement of reinforced foundation bed corresponding to the footing pressure equal to the ultimate bearing pressure of unreinforced foundation bed. Figure 7 shows the PRS values for different forms and combination of the reinforcement. The maximum PRS $=97 \%$ was observed in the case of the clay bed reinforced with bamboo cell and bamboo grids. PRS $=97 \%$ means, $97 \%$ reduction in the settlement in the reinforced bed as compared to the unreinforced clay bed. Bamboo cell, due to its beam action disperses the load to wider areas. Due to this, the loading intensity on the soil will be lesser than what it supposed to be. This action leads to the reduction in the settlement of the bed. In addition, basal bamboo grid further reduces the settlement of the bed by resisting the downward movement of soil when the load is applied.

The stiffness of the foundation bed can be estimated in terms of modulus of subgrade reaction $\left(K_{\mathrm{s}}\right)$. Modulus of subgrade reaction represents the stiffness of the soil bed at lower settlements. It is defined as the pressure corresponding to the $1.25 \mathrm{~mm}$ settlement in the load settlement behavior [23]. Mathematically, $K_{\mathrm{s}}$ can be represented as

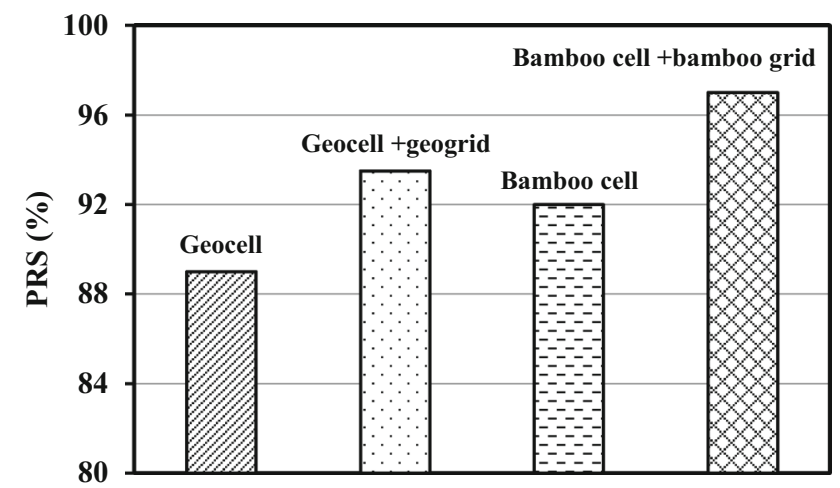

Fig. 7 PRS values observed for the different types and combination of reinforcement 
$K_{\mathrm{s}}\left(\mathrm{kN} / \mathrm{m}^{3}\right)=\frac{q_{1.25}(\mathrm{kPa})}{1.25 \times 10^{-3}}$

where, $q_{1.25}$ is the uniform pressure applied to the plate at $1.25 \mathrm{~mm}$ of settlement. Generally, the modulus of subgrade reaction is used in the design of roads and airfield pavements. The $K_{\mathrm{s}}$ value calculated from Fig. 5 for different cases are listed in Table 3. The stiffness of the foundation bed found to increase due to the provision of the reinforcement. As compared to unreinforced bed, the maximum increment in the stiffness of 11 times was observed when the foundation bed was reinforced with combination of bamboo cell and bamboo grid.

Figure 8 represents the variation of the surface deformation (settlement/heave) with the footing settlement for different type of reinforcements. Surface deformation measurements were made through the dial gauges placed at the distance of $1.5 \mathrm{~B}$ from the centreline of the model footing plate. Chummar [18] observed that the surface heaving extends up to $2 B$ from the centreline of the footing in case of the unreinforced bed and with maximum heaving occurring at a distance of $1.5 \mathrm{~B}$. Surface deformation in the form of heaving equal to $2 \%$ of the footing width was observed in case of the unreinforced clay bed. Generally, surface heaving can be attributed to the shear failure of the soil mass. Surface heaving was completely eliminated when the clay bed was reinforced with geocell or bamboo cell. Instead, the settlement of the fill was observed in the presence of reinforcement. The fill settlement up to $2 \%$ of the footing width was observed in case of the only geocell. The settlement of the fill was reduced when basal geogrid was provided. The least settlement of the fill was observed in the case of combination of bamboo cell and bamboo grid.

\section{Analytical Formulations}

In this section, the hypothesis proposed by Sitharam and Hegde [24] to estimate the bearing capacity of the clay bed reinforced geocells has been extended to bamboo cells. The increase in load carrying capacity of the bamboo cell reinforced foundation beds is mainly contributed by two

Table 3 Modulus of subgrade reaction $\left(K_{\mathrm{s}}\right)$ values for different cases

\begin{tabular}{ll}
\hline Case considered & $\begin{array}{l}\text { Modulus of subgrade } \\
\text { reaction, } K_{\mathrm{s}}\left(\mathrm{kN} / \mathrm{m}^{3}\right)\end{array}$ \\
\hline Unreinforced & 2189 \\
Geocell & 16,642 \\
Geocell + geogrid & 22,348 \\
Bamboo cell & 16,667 \\
Bamboo cell + bamboo grid & 23,899 \\
\hline
\end{tabular}

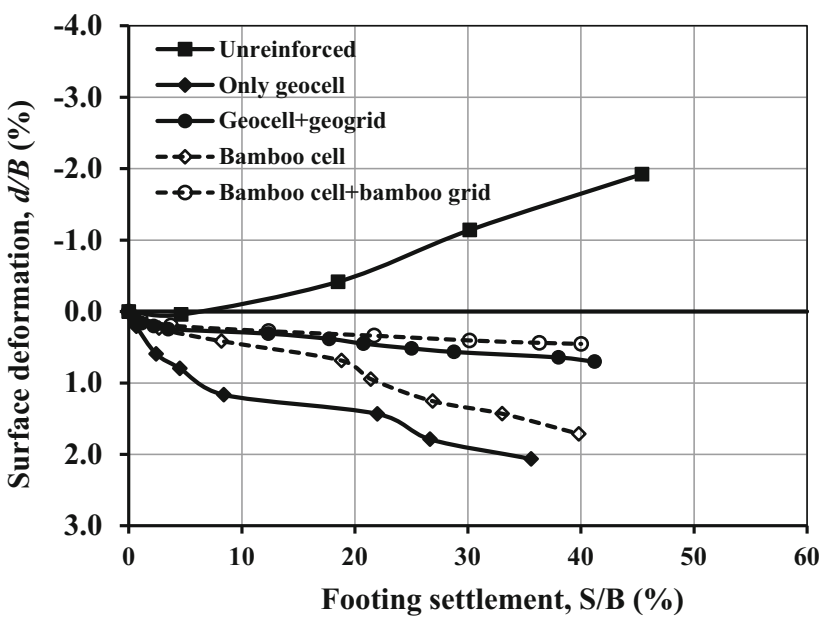

Fig. 8 Variation of surface deformation with footing settlement

mechanisms, namely lateral resistance effect and the vertical stress dispersion effect. In case, if the basal bamboo grid is provided below the bamboo cell mattress, then the third mechanism called membrane effect comes into the formulation. Hence, the increase in load carrying capacity of the bamboo cell and bamboo grid reinforced foundation bed $(\Delta P)$ can be given by,

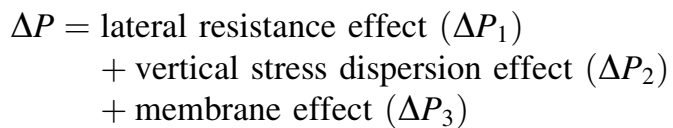

The term lateral resistance effect used in the formulation indicates the mobilization of the additional shear strength $(\tau)$ in the clay bed due to the interaction between the inner surface of the bamboo cell and the infill soil. Figure 9 represents the mechanism of mobilization of shear strength due to wall-soil friction. The inner surface of the bamboo cell has a unique texture. When infill soil comes in contact with these textures, friction force will develop between the material and the bamboo cell inner surface. The friction force, thus originated not only resists the imposed load, but also helps to increase the bearing capacity of the reinforced clay beds [16].

The lateral resistance effect component $\left(\Delta P_{1}\right)$ is calculated using Koerner [25] method:

$\Delta P_{1}=2 \tau$

where $\tau$ is the shear strength between the bamboo cell wall and the infill soil (sand) and is given by,

$\tau=P_{\mathrm{r}} \tan ^{2}(45-\varphi / 2) \tan \delta$

where $P_{\mathrm{r}}$ is the applied vertical pressure on the bamboo cell, $\varphi$ is the friction angle of the sand $\left(\varphi=36^{\circ}\right.$ in the present case) used to fill the cell pockets and $\delta$ is the angle of shearing resistance between the bamboo cell wall and the soil contained within. The angle of shearing resistance is also called as interface friction angle and is determined 


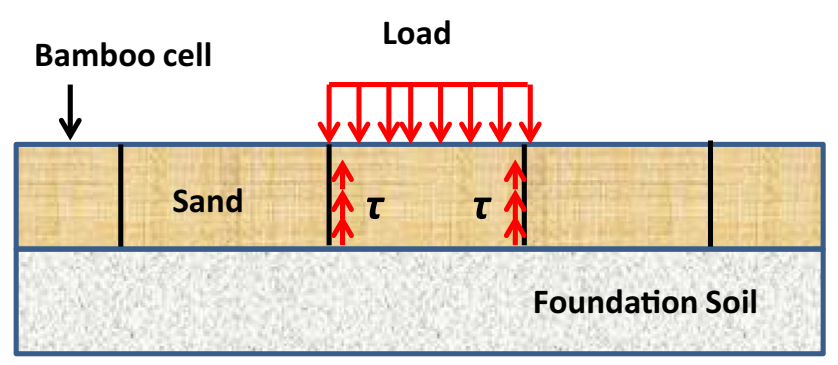

Fig. 9 Mechanism of mobilization of shear strength due to wall-soil friction

from the modified direct shear test. The value of $\delta$ obtained in the present case is equal to $32^{\circ}$.

The vertical stress dispersion mechanism is also called as the wide slab mechanism. Figure 10 shows the schematic representation of the vertical stress dispersion mechanism in the bamboo cell reinforced foundation beds. Footing of width $B$ resting on the bamboo cell reinforcement behaves as if the footing of width $B+\Delta B$ resting on soft soil at the depth of $D_{\mathrm{r}}$, where $D_{\mathrm{r}}$ is the depth of the reinforcement. $\beta$ is the load dispersion angle, measured with respect to the vertical direction as shown in Fig. 10. Generally, $\beta$ varies between a minimum value of $26^{\circ}$ (1H: $2 \mathrm{~V})$ to maximum of $45^{\circ}(1 \mathrm{H}: 1 \mathrm{~V})$ [26]. To be conservative, the least angle of dispersion i.e. $\beta=26^{\circ}$ was considered in the analysis. If $P_{\mathrm{r}}$ is the applied pressure on the footing with width $B$, then the actual pressure transferred to the soil subgrade is less than $P_{\mathrm{r} \text {. }}$ Reduction in the pressure due to provision of bamboo cell $\left(\Delta P_{2}\right)$ is obtained as,

$\Delta P_{2}=P_{\mathrm{r}}\left(1-\frac{B}{B+2 D_{\mathrm{r}} \tan \beta}\right)$

The membrane effect mechanism is contributed by the vertical component of the mobilized tensile strength of the planar reinforcement in case it is provided [27]. The increase in the load carrying capacity due to the membrane effect $\left(\Delta P_{3}\right)$ is given by,

$\Delta P_{3}=\frac{2 T \sin \alpha}{B}$

where, $T$ is the tensile strength of the basal bamboo grid. $\operatorname{Sin} \alpha$ is calculated as the function of settlement. The deformed shape of bamboo grid is generally parabolic in nature. However, if the footing dimension is very small compared to the bamboo grid dimension, then it resembles the triangular shape. In the present case, bamboo grid dimension is 5.5 times larger than the footing dimension and hence, the triangular shape was considered as indicated by the dotted line in Fig. 11,

$\sin \alpha=\frac{2 S}{B_{\mathrm{g}}}$

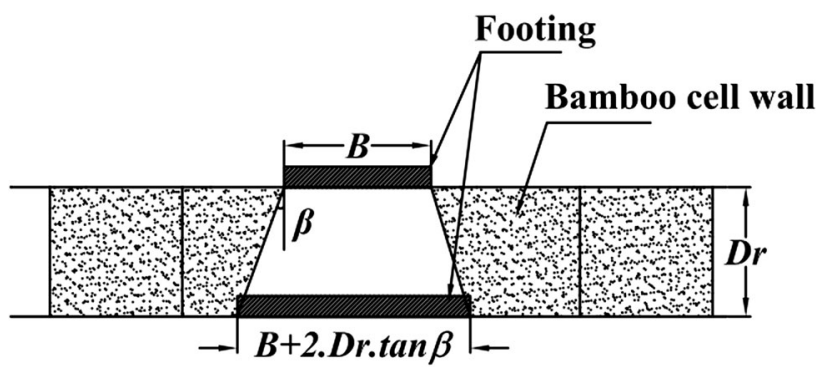

Foundation soil

Fig. 10 Vertical stress dispersion mechanism

where $B_{\mathrm{g}}$ is the width of the basal bamboo grid and $S$ is the footing settlement measured at the surface.

The increase in the load carrying capacity of the foundation bed reinforced with combination of bamboo cell and bamboo grid is represented as:

$$
\begin{aligned}
\Delta P & =2 P_{\mathrm{r}} \tan ^{2}(45-\varphi / 2) \tan \delta \\
& +P_{\mathrm{r}}\left(1-\frac{B}{B+2 D_{\mathrm{r}} \tan \beta}\right)+\frac{2 T \sin \alpha}{B}
\end{aligned}
$$

The increase in the load carrying capacity of the foundation bed is expressed in terms of applied pressure on the bamboo cell mattress $\left(P_{\mathrm{r}}\right)$, tensile strength of the bamboo grid $(T)$ and the allowable limiting settlement $(S)$. It is very relevant to express the increase in load carrying capacity in terms of pressure applied on the bamboo mattress because of the mobilization of shear strength at the cell wall is directly related to applied pressure.

\section{Comparison of Analytical and Experimental Results}

Figure 12 represents the comparison of experimental and analytically predicted $\Delta P-S$ curves for the two cases viz. only bamboo cell reinforced case and combination of bamboo cell and bamboo grid reinforced case. There exists a good match between measured and calculated $\Delta P$ values at the different settlements. Membrane effect was not considered in the evaluation of the increase in the load carrying capacity of the foundation bed reinforced with only bamboo cell. In case of the clay bed reinforced with bamboo cell and bamboo grid, a good match between the experimental and analytical results was obtained when the tensile strength of the basal bamboo grid was equal to $3 \%$ of its ultimate tensile strength. In other words, it can also interpret that only $3 \%$ of the ultimate tensile strength of the bamboo grid was mobilized while resisting the footing load. Kindly refer Tables 4 and 5 in appendix A for the detailed calculation of the increase in bearing capacity for the two cases considered. 


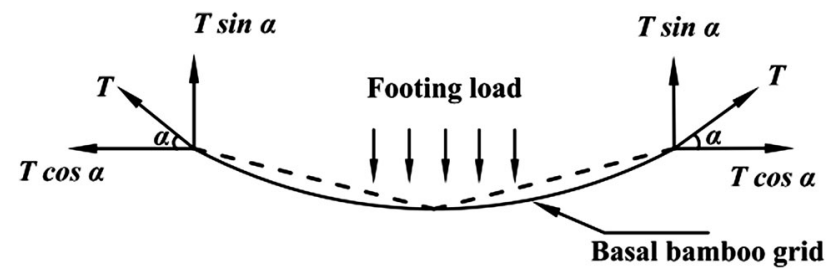

Fig. 11 Deformed basal geogrid contributing to membrane effect

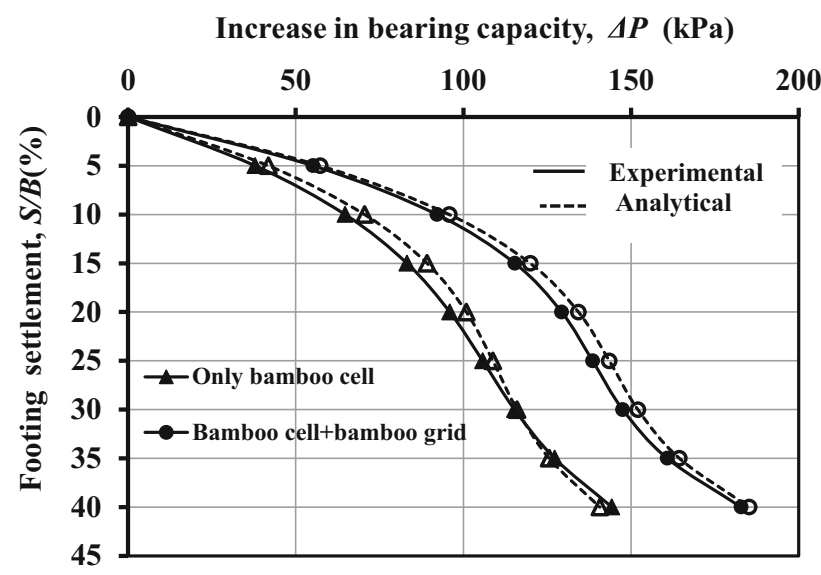

Fig. 12 Comparison of measured and calculated $\Delta P-S$ curve

\section{Conclusions}

The efficacy of the bamboo as a soil reinforcement has been studied by means of experimental and analytical studies. Bamboo was innovatively and effectively utilized by forming bamboo cells and bamboo grids from the locally available bamboo. The following conclusions can be drawn from the study.

1. The tensile strength of the bamboo was found to be nine times higher than geocells and geogrids. Bamboo mobilizes the full tensile strength at the strain less than $3 \%$, makes it ideal for the geotechnical problems involving low strains like foundation problems.
2. It is always beneficial to use the combination of bamboo cell and bamboo grid than using them alone. The ultimate bearing capacity of the clay bed reinforced with combination of bamboo cell and bamboo grid is 1.2-1.5 times higher than that of the geocell and geogrid reinforced clay beds. The surface deformation of the foundation bed was reduced by $35 \%$ in the presence of bamboo cell and bamboo grid as compared to their geosynthetic counterparts.

3. Increase in load carrying capacity of the bamboo cell and bamboo grid reinforced foundation bed is contributed by three main mechanisms, namely lateral resistance effect, vertical stress dispersion effect and membrane effect. By knowing the pressure applied on the bamboo cell, tensile strength of the bamboo grid and the limiting settlement, the increment in the load carrying capacity can be calculated.

4. The predicted results $(\Delta P-S)$ from the analytical model were found to be in good agreement with the experimental results. Analytical model seems to be simple and elegant in predicting the bearing capacity of the bamboo reinforced foundation beds.

In addition, bamboo is highly cost effective and environmental friendly. Bamboo is not responsible for the emission of greenhouse gases and will not leave any carbon footprint. In overall, it can be concluded that bamboo has many advantages over geosynthetics products and can be effectively used as the alternative to geocell and geogrids in the regions where it is available in abundance. It should be noted that only one type of geocells (i.e. Neoloy made geocells) and only one type of geogrids (i.e. Polypropylene made geogrids) were used in the study. Hence, the presented results are applicable to limited cases.

\section{Appendix A}

Table 4 Comparison of analytical and experimental results: combination of bamboo cell and bamboo grid

\begin{tabular}{lcccccccrr}
\hline$S / B(\%)$ & $S(\mathrm{~m})$ & $\begin{array}{l}P_{\mathrm{r}}(\mathrm{kPa}) \\
\text { experiment }\end{array}$ & $\Delta P_{1}(\mathrm{kPa})$ & $\Delta P_{2}(\mathrm{kPa})$ & $\Delta P_{3}(\mathrm{kPa})$ & $\begin{array}{l}\Delta P=\Delta P_{1}+\Delta P_{2}+ \\
\Delta P_{3}(\mathrm{kPa})\end{array}$ & $\begin{array}{l}P_{\mathrm{u}}(\mathrm{kPa}) \\
\text { experiment }\end{array}$ & $\begin{array}{l}\Delta P=P_{\mathrm{r}}-P_{\mathrm{u}}(\mathrm{kPa}) \\
\text { experiment }\end{array}$ \\
\hline 0 & 0.00 & 0.0 & 0.00 & 0.00 & 0.00 & 0.00 & 0.00 & 0.00 \\
5 & 0.01 & 67.7 & 21.97 & 33.44 & 1.87 & 57.29 & 12.55 & 55.17 \\
10 & 0.02 & 112.4 & 36.48 & 55.52 & 3.75 & 95.74 & 20.32 & 92.11 \\
15 & 0.02 & 139.7 & 45.32 & 68.97 & 5.62 & 119.90 & 24.36 & 115.31 \\
20 & 0.03 & 155.0 & 50.29 & 76.54 & 7.48 & 134.31 & 25.46 & 13.29 \\
25 & 0.04 & 164.0 & 53.20 & 80.96 & 9.33 & 143.50 & 24.61 & 147.50 \\
30 & 0.05 & 172.1 & 55.84 & 84.99 & 11.18 & 152.01 & 24.23 & 160.77 \\
35 & 0.05 & 185.0 & 60.02 & 91.35 & 13.01 & 164.38 & 25.37 & 182.79 \\
40 & 0.06 & 208.2 & 67.54 & 102.79 & 14.83 & 185.16 & \\
\hline
\end{tabular}


Table 5 Comparison of analytical and experimental results: only bamboo cell

\begin{tabular}{lccccccc}
\hline$S / B(\%)$ & $S(\mathrm{~m})$ & $\begin{array}{l}P_{\mathrm{r}}(\mathrm{kPa}) \\
\text { experiment }\end{array}$ & $\Delta P_{1}(\mathrm{kPa})$ & $\Delta P_{2}(\mathrm{kPa})$ & $\Delta P=\Delta P_{1}+\Delta P_{2}(\mathrm{kPa})$ & $\begin{array}{l}P_{\mathrm{u}}(\mathrm{kPa}) \\
\text { experiment }\end{array}$ & $\begin{array}{l}\Delta P=P_{\mathrm{r}}-P_{\mathrm{u}}(\mathrm{kPa}) \\
\text { experiment }\end{array}$ \\
\hline 0 & 0.00 & 0.0 & 0.00 & 0.00 & 0.00 & 0.00 & 0.00 \\
5 & 0.01 & 50.4 & 16.37 & 25.46 & 41.83 & 12.55 & 37.90 \\
10 & 0.02 & 85.0 & 27.59 & 42.92 & 70.51 & 20.32 & 64.72 \\
15 & 0.02 & 107.5 & 34.89 & 54.27 & 89.16 & 24.36 & 83.16 \\
20 & 0.03 & 121.7 & 39.47 & 61.40 & 100.88 & 25.46 & 105.73 \\
25 & 0.04 & 131.2 & 42.56 & 66.21 & 108.78 & 24.61 & 115.25 \\
30 & 0.05 & 139.9 & 45.38 & 70.59 & 115.97 & 24.23 & 127.20 \\
35 & 0.05 & 151.4 & 49.13 & 76.43 & 125.56 & 25.37 & 144.27 \\
40 & 0.06 & 169.6 & 55.04 & 85.62 & 140.66 & \\
\hline
\end{tabular}

\section{Formulas}

$\Delta P_{1}=2 P_{\mathrm{r}} \tan ^{2}(45-\varphi / 2) \tan \delta \quad\left(\varphi=36^{\circ}, \delta=32^{\circ}\right)$

$$
\begin{aligned}
& \Delta P_{2}=P_{\mathrm{r}} \quad\left(1-\frac{B}{B+2 \times D_{\mathrm{r}} \times \tan \beta}\right) \\
& \left(B=0.15 \mathrm{~m}, D_{\mathrm{r}}=0.15 \mathrm{~m}, \beta=26^{\circ}\right) \\
& \Delta P_{3}=\frac{2 T \sin \alpha}{B} \quad(B=0.15 \mathrm{~m}, T=7.5 \mathrm{kN} / \mathrm{m})
\end{aligned}
$$

\section{References}

1. Han J, Yang X, Leshchinsky D, Parsons RL (2008) Behaviour of geocell reinforced sand under a vertical load. J Transp Res Board 2045:95-101

2. Han J, Pokhrel SK, Yang X, Manandhar C, Leshchinsky D, Halahmi I, Parsons RL (2011) Performance of geocell reinforced RAP bases over weak subgrade under full scale moving wheel loads. J Mater Civ Eng 23(11):1525-1534

3. Thakur JK, Han J, Pokharel SK, Parsons RL (2012) Performance of geocell-reinforced recycled asphalt pavement (RAP) bases over weak subgrade under cyclic plate loading. Geotext Geomembr 35:14-24

4. Moghaddas Tafreshi SN, Khalaj O, Dawson AR (2013) Pilotscale load tests of a combined multi-layered geocell and rubberreinforced foundation. Geosynth Int 20(3):143-161

5. Leshchinsky B, Ling H (2013) Effects of geocell confinement on strength and deformation behaviour of gravel. J Geotech Geoenviron Eng 139(2):340-352

6. Hegde A, Sitharam TG (2014) Joint strength and wall deformation characteristics of a single cell subjected to uniaxial compression. Int J Geomech ASCE. doi:10.1061/(ASCE)GM.19435622.0000433

7. Hegde A, Kadabinakatti S, Sitharam TG (2014) Protection of buried pipelines using a combination of geocell and geogrid reinforcement: experimental studies. Ground Improvement and Geosynthetics, Geotechnical Special Publication-238, ASCE: 289-298
8. Hegde A, Sitharam TG (2015) 3-dimensional numerical modelling geocell reinforced sand beds. Geotext Geomembr. doi:10. 1016/j.geotexmem.2014.11.009

9. Hegde AM, Sitharam TG (2015) 3-Dimensional numerical analysis of geocell reinforced soft clay beds by considering the actual geometry of geocell pockets. Can Geotech J. doi:10.1139/cgj2014-0387

10. Hegde A, Sitharam TG (2013) Experimental and numerical studies on footings supported on geocell reinforced sand and clay beds. Int J Geotech Eng 7(4):347-354

11. Adrianus R, Tambunan W, Supriyatin LK, Watimena C, Sudrajat H, Yusuf M (2010) Durability assessment of chemically treated bambusa blumeana. World J Fungal Plant Biol 1(2):32-36

12. Khatib A (2009) Bearing capacity of granular soil overlying soft clay reinforced with Bamboo-geotextile composite at the Interface. $\mathrm{PhD}$ Thesis, Department of Geotechnics and Transportation, Faculty of Civil Engineering, University Technology Malaysia

13. Toh CT, Chee SK, Lee CH, Wee SH (1994) Geotextile-bamboo fascine mattress for filling over very soft soils in Malaysia. Geotext Geomembr 13:357-369

14. Prasad DSV, Anjan Kumar M, Prasada Raju GVR (2010) Behavior of reinforced sub bases on expansive soil sub grade. Glob J Res Eng 10:2-8

15. Marto A, Othman BA (2011) The potential use of bamboo as green material for soft clay reinforcement system. In: International Conference on Environment Science and Engineering, Singapore IPCBEE 8:129-133

16. Hegde AM, Sitharam TG (2014) Effect of infill materials on the performance of geocell reinforced soft clay beds. Geomech Geoengin. doi:10.1080/17486025.2014.921334

17. Selig ET, McKee KE (1961) Static and dynamic behaviour of small footings. J Solid Mech Found Div ASCE 87:29-47

18. Chunmar AV (1972) Bearing capacity theory from experimental results. J Geotech Eng Div ASCE 98(12):1311-1324

19. ASTM D 6637 (2011) Standard test method for determining the tensile properties of geogrid by the single or multi-rib tensile method. ASTM International, West Conshohocken

20. Zreik DA, Ladd CC, Germaine JT (1995) A new fall cone device for measuring the undrained strength of very weak cohesive soils. Geotech Test J 18(4):472-482

21. Binquet J, Lee LK (1975) Bearing capacity tests on reinforced earth slabs. J Geotech Eng Div ASCE 101(12):1241-1255

22. Vesic AS (1973) Analysis of ultimate loads of shallow foundations. J Soil Mech Found Div 99:45-69 
23. DIN 18134 (2001) Determining the deformation and strength characteristics of soil by plate loading tests. German standard, Berlin 10772

24. Sitharam TG, Hegde A (2013) Design and construction of geocell foundation to support embankment on soft settled red mud. Geotext Geomembr 41:55-63

25. Koerner RM (1998) Designing with geosynthetics. Prentice Hall, New Jersey
26. Gabr MA, Doson R, Collin JG (1998) A study of stress distribution in geogrid reinforced sand. In: Proceeding of geosynthetics in foundation reinforcement and erosion control systems, (GSP-76), ASCE, Massachusetts, 62-76

27. Zhang L, Zhao M, Shi C, Zhao H (2010) Bearing capacity of geocell reinforcement in embankment engineering. Geotext Geomembr 28:475-482 